\title{
Water Vapor Transfer over the Southwest Pacific: Mean Patterns and Variations during Wet and Dry Periods
}

\author{
M. M. KHATEP AND B. B. FitzhaRRIS \\ Department of Geography, University of Otago, New Zealand \\ W. E. BARDSLEY \\ Department of Earth Sciences, University of Waikato, New Zealand
}

(Manuscript received 19 January 1983, in final form 21 May 1984)

\begin{abstract}
The mean water vapor transfer of the Southwest Pacific, as determined from radiosonde records near the $170^{\circ} \mathrm{E}$ meridional transect, is computed for the 1960-73 period. Emphasis is placed on defining average patterns, then examining variations that arise during the wettest and driest years and seasons in New Zealand over that period. Over the midlatitudes, the mean transfer is predominantly from the west, and most developed in summer. Over the subtropics, the mean summer transfer is predominantly from the north or northeast, but in winter a northwest flow prevails. Patterns of water vapor transfer during wet and dry periods over New Zealand differ more in direction than in magnitude, with the subtropical easterlies extending farther poleward during wet periods, especially in summer.
\end{abstract}

\section{Introduction}

The flux of water vapor in the atmosphere constitutes a major component of the global hydrological cycle, and is subject to considerable variation (Rosen et al., 1979). Although several workers discuss atmospheric water vapor transfer over the Southwest Pacific (Starr et al., 1969; Starr and Peixoto, 1971; Peixoto, 1972; Peixoto et al., 1976; Peixoto et al., 1978), their coverage of the region is, in general, only a part of larger studies and restricted to short time periods, often one year. This paper presents a more detailed analysis for the region since zonal, meridional, and vector water vapor transfers are calculated for six radiosonde stations near the $170^{\circ} \mathrm{E}$ meridional transect (see Fig. 1, Table 1), from Nadi $\left(17^{\circ} 46^{\prime} \mathrm{S}\right)$ to Campbell Island $\left(52^{\circ} 33^{\prime} \mathrm{S}\right)$ over the period 1960-73.

As noted by Rosen et al. (1979), most studies of large scale moisture flux emphasize average patterns rather than departures on a year to year or seasonal basis. In order to make the present study as complete as possible, the second part of the paper is concerned with an investigation of characteristics of short-term averages of water vapor transfer during the wettest and driest periods of 1960-73 over New Zealand. Hereafter, these periods will be abbreviated "wet" and "dry." Such an analysis is of practical importance to a country where weather-dependent agricultural exports dominate the economy, and provide $70 \%$ of its overseas earnings.

From the data of Tomlinson (1980), the 1960-73 rainfall average, as obtained from the mean of 20 representative stations spread throughout New Zealand, was within $1 \%$ of the corresponding long-term average calculated from 1900-78. However, rainfall over the latter part of the 1960-73 study period was the lowest for forty years over much of the country. The period of study is thus "representative" in that it is close to the long-term average while at the same time it includes a considerable rainfall range for individual years and seasons.

New Zealand has high relief, with the main axial ranges running southwest to northeast, and reaching an elevation of $3764 \mathrm{~m}$ (Fig. 1). The mean wind flow is from the west/southwest, but there are variations depending on the frequency of fronts, depressions, and wave cyclones in the westerlies, together with occasional tropical cyclones from the north. The orientation of the airflow ahead of or behind these disturbances determines the spatial distribution of rainfall over New Zealand. Salinger (1980) demonstrates that precipitation anomalies are strongly localized, because the rugged topography triggers orographic precipitation on most windward coasts.

Salinger (1980) showed that months with negative pressure anomalies to the south of the country (i.e., a westerly circulation predominates), are associated with rainfalls higher than normal in the west, and lower in the east and north. Conversely, whenever pressures are lower than average to the north of New Zealand, a more easterly flow develops, so that the north and east are wetter than normal, and the south

(ㄷ) 1984 American Meteorological Society 


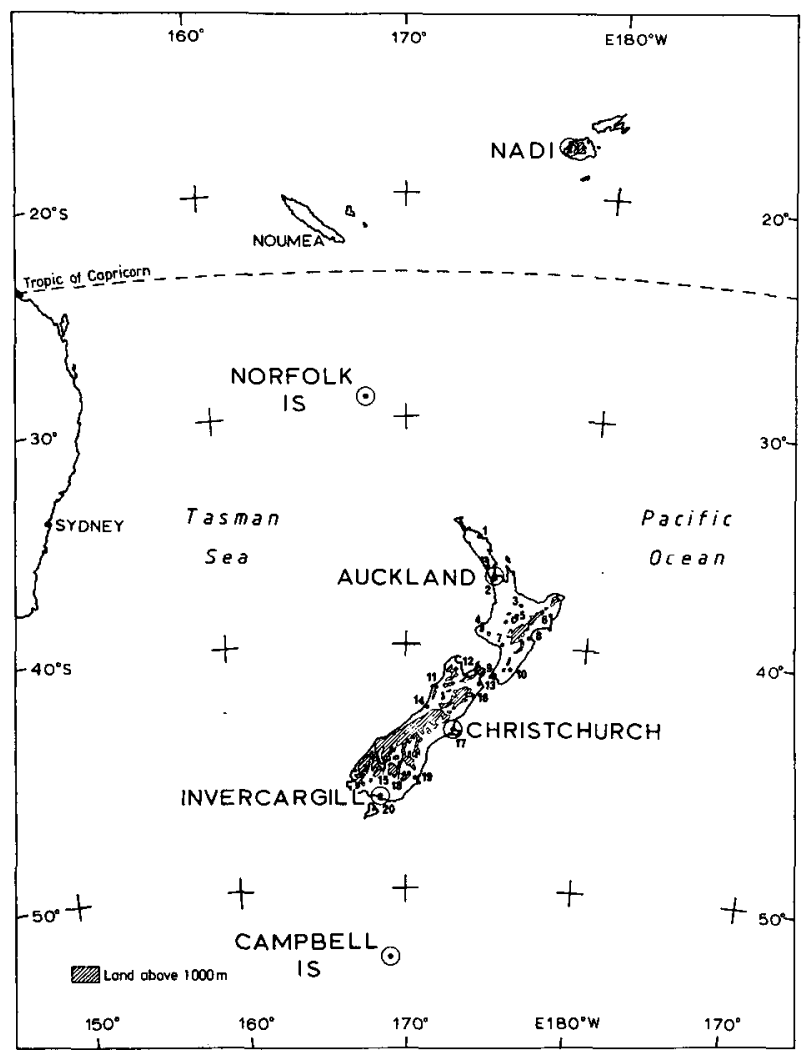

FIG. 1. Location of the radiosonde stations along the Southwest Pacific meridional transect and of rainfall stations given in Table 2.

and west drier. Previously Trenberth (1977) had investigated the relationships among inflow into hydro lakes, precipitation, and broad scale atmospheric circulation patterns in the southwest of the country. He also found that precipitation was associated with westerlies and also northerlies to a lesser extent. Southerlies were not found to be favorable to precipitation. A major factor in the northerly flow precipitation was considered to be the increased moisture transported into the hydro lake region from the tropics.

There are also pronounced secular fluctuations in annual rainfall over New Zealand (Tomlinson, 1976, 1980, Vines and Tomlinson, 1980). By using a set of four filters, which relate to the approximately 21 year double sunspot cycle and its first and second harmonies, these authors showed that a definite nonrandom element exists in New Zealand's temporal rainfall over the period 1900-78. The years in the early 1910s, 1920s, 1930s and 1970s tended to be dry, while groups of wetter years occurred regularly in each decade. The present study goes some way toward a causal explanation of such fluctuations through linking wet and dry periods to specific patterns of vapor flux.
While studies have examined abnormal climatic periods elsewhere in the world (e.g., Hastenrath and Heller, 1977; Kidson, 1977; Kanamitsu and Krishnamurti, 1978; Nicholson, 1981), there has been little attempt to investigate whether these periods are accompanied by changes in the vapor flux field. Kidson (1977) was restricted by the incompleteness of his humidity data, but he noted that it was unfortunate this "prevented a comparison of the vapor budgets for wet and dry years." Wetter and drier periods could also be related to other parameters such as variations in the divergence of the vapor flux, the divergence and vorticity of the velocity field, the vertical motion, and in tropospheric static stability. However, divergence calculations require radiosonde stations to be distributed over an area, and are not suitable where stations are along a transect as is the case in this study, and information on vertical motion was not available.

\section{Data and procedures}

For a given level in the atmosphere the magnitude of the instantaneous zonal, meridional and vector transfer of water vapor is defined by

where

$$
\begin{aligned}
Q \lambda_{L} & =g^{-1} q u, \\
Q \phi_{L} & =g^{-1} q v, \\
\mathbf{Q}_{\mathbf{L}} & =g^{-1} q \mathbf{c},
\end{aligned}
$$

$Q \lambda_{L} \quad$ zonal water vapor transfer for a given level $\left(\mathrm{kg} \mathrm{m}^{-1} \mathrm{mb}^{-1} \mathrm{~s}^{-1}\right)$,

$Q \phi_{L} \quad$ meridional water vapor transfer for a given level $\left(\mathrm{kg} \mathrm{m}^{-1} \mathrm{mb}^{-1} \mathrm{~s}^{-1}\right)$,

$\mathbf{Q}_{\mathrm{L}}$ vector transfer of water vapor for a given

$$
\text { level }\left(\mathrm{kg} \mathrm{m}^{-1} \mathrm{mb}^{-1} \mathrm{~s}^{-1}\right) \text {, }
$$

$g$ acceleration due to gravity $\left(9.81 \mathrm{~m} \mathrm{~s}^{-2}\right)$,

$q$ specific humidity $\left(\mathrm{g} \mathrm{kg}^{-1}\right)$,

c vector wind (magnitude: $\mathrm{m} \mathrm{s}^{-1}$; direction: true ${ }^{\circ}$ ),

$u$ zonal wind component $\left(\mathrm{m} \mathrm{s}^{-1}\right)$,

$v$ meridional wind component $\left(\mathrm{m} \mathrm{s}^{-1}\right)$.

The vertically integrated magnitude of the instantaneous transfer of water vapor $\left(\mathrm{kg} \mathrm{m}^{-1} \mathrm{~s}^{-1}\right)$ is approximated by

$$
\begin{aligned}
& Q \lambda=g^{-1} \int_{p_{s}}^{400} q u d p \\
& Q_{\phi}=g^{-1} \int_{p_{s}}^{400} q v d p \\
& \mathbf{Q}=g^{-1} \int_{p_{s}}^{400} q \mathrm{c} d p
\end{aligned}
$$

and the total amount of precipitable water $\left(\mathrm{kg} \mathrm{m}^{-2}\right)$ is obtained by similar integration 
TABLE 1. Characteristics of radioscinde stations.

\begin{tabular}{|c|c|c|c|c|}
\hline Station & Latitude & Longitude & $\begin{array}{l}\text { Elevation } \\
(\mathrm{m})\end{array}$ & Surrounding terrain \\
\hline Nadi & $17^{\circ} 46^{\prime} \mathrm{S}$ & $177^{\circ} 21 \mathrm{E}$ & 18 & $\begin{array}{l}\text { This airport station is on the NW of the island of Viti Levu } \\
\text { ind in the lee of } 1300 \mathrm{~m} \text { high mountains } 20 \mathrm{~km} \text { to the } \\
\text { tast. }\end{array}$ \\
\hline Norfolk Island & $29^{\circ} 03^{\prime} \mathrm{S}$ & $167^{\circ} 51^{\prime} \mathrm{E}$ & 109 & $\begin{array}{l}\text { The island is } 8 \mathrm{~km} \text { long and } 5 \mathrm{~km} \text { wide. Highest point is } \\
317 \mathrm{~m} \text { and the station is on the SW of the island. }\end{array}$ \\
\hline Auckland & $37^{\circ} 01^{\prime} \mathrm{S}$ & $174^{\circ} 48^{\prime} \mathrm{E}$ & 7 & This airport station is surrounded by low land or sea. \\
\hline Christchurch & $43^{\circ} 29^{\prime} \mathrm{S}$ & $172^{\circ} 33^{\prime} \mathrm{E}$ & 36 & $\begin{array}{l}\text { This airport station is located on an open plain, but in the } \\
\text { lee of the Southern Alps }(3000 \mathrm{~m}) 80 \mathrm{~km} \text { to the west. }\end{array}$ \\
\hline Invercargill & $46^{\circ} 25^{\prime} \mathrm{S}$ & $168^{\circ} 20 \mathrm{E}$ & 2 & $\begin{array}{l}\text { This airport station is at the southern margin of an } \\
\text { extensive plain. Nearest high ground is } 40 \mathrm{~km} \text { to } \\
\text { northwest. }\end{array}$ \\
\hline Campbell Island & $52^{\circ} 33^{\prime} \mathrm{S}$ & $169^{\circ} 09^{\prime} \mathrm{E}$ & .15 & $\begin{array}{l}\text { The island is } 16 \mathrm{~km} \text { in diameter with rugged hills } 300-570 \\
\text { in high. The station is on an inlet } 7 \mathrm{~km} \text { from ocean. }\end{array}$ \\
\hline
\end{tabular}

$$
w=g^{-1} \int_{p_{s}}^{400} q d p
$$

where $p_{s}$ is surface pressure.

The mean of the above parameters over a specified time period is defined by the function

$$
(\bar{x})=T^{-1} \int_{0}^{T}(x) d t,
$$

where the bar operator denotes a time average of the specified quantity $(x)$ for the time interval $T$.
The basic data for the computation of the above parameters consist of surface and upper air measurements of mixing ratio and wind, as observed once or twice daily (at 0000 and sometimes at 1200 GMT) at the six radiosonde stations for the period 1960 to 1973 . Details of the stations are given in Table 1. Less than $0.5 \%$ of the observations are missing. In the calculation of the abovementioned parameters, observations at eight or more pressure levels were used (surface, 900, 850, 800, 700, 600, 500, $400 \mathrm{mb}$, and in some cases 950 and $750 \mathrm{mb}$ as well).

TABLE 2: Wet and dry periods from the period 1960-73 selected for analysis, and the spatial distribution of rainfall over New Zealand.

\begin{tabular}{|c|c|c|c|c|c|c|c|}
\hline $\begin{array}{l}\text { Station } \\
\text { number }\end{array}$ & Station name & $\begin{array}{c}\text { Dry year } \\
1973\end{array}$ & $\begin{array}{c}\text { Wet year } \\
1968\end{array}$ & $\begin{array}{c}\text { Dry summer } \\
1972-73\end{array}$ & $\begin{array}{c}\text { Wet summer } \\
1965-66\end{array}$ & $\begin{array}{l}\text { Dry winter } \\
1969\end{array}$ & $\begin{array}{c}\text { Wet winter } \\
1968\end{array}$ \\
\hline 1 & Kerikeri & 79 & 115 & 60 & 151 & 73 & 120 \\
\hline 2 & Auckland & 86 & 130 & 31 & 164 & 86 & 117 \\
\hline 3 & Rotorua & 74 & 99 & 48 & 169 & 60 & 125 \\
\hline 4 & New Plymouth & 98 & 102 & 49 & 112 & 107 & 77 \\
\hline 5 & Taupo & 77 & 93 & 61 & 136 & 50 & 115 \\
\hline 6 & Gisborne & 97 & 98 & 96 & 68 & 57 & 164 \\
\hline 7 & Wanganui & 73 & 94 & 37 & 87 & 85 & 88 \\
\hline 8 & Napier & 101 & 102 & 62 & 131 & 62 & 138 \\
\hline 9 & Wellington & 82 & 107 & 36 & 113 & 66 & 106 \\
\hline 10 & Masterton & 77 & 91 & 28 & 83 & 57 & 87 \\
\hline 11 & Westport & 91 & 122 & 83 & 102 & 61 & 123 \\
\hline 12 & Nelson & 66 & -102 & 26 & 114 & 36 & 130 \\
\hline 13 & Blenheim & 64 & 106 & 12 & 133 & 19 & 119 \\
\hline 14 & Hokitika & 91 & 111 & 60 & 127 & 69 & 117 \\
\hline 15 & Queenstown & 87 & 107 & 51 & 90 & 87 & 115 \\
\hline 16 & Kaikoura & 58 & 96 & 48 & 70 & 62 & 135 \\
\hline 17 & Christchurch & 76 & 116 & 40 & 74 & 40 & 105 \\
\hline 18 & Alexandra & 91 & 127 & 39 & 118 & 64 & 182 \\
\hline 19 & Dunedin & 85 & 130 & 52 & 118 & 59 & 85 \\
\hline 20 & Invercargill & 95 & 105 & 80 & 85 & 96 & 84 \\
\hline \multicolumn{8}{|c|}{ Average for New Zealand } \\
\hline (\% of & al) & 84 & 107 & 54 & 116 & 67 & 114 \\
\hline \multicolumn{2}{|c|}{$\begin{array}{l}\text { (\% of normal) } \\
\text { Actul New Zealand rainfall }\end{array}$} & & & & & + & \\
\hline \multicolumn{2}{|c|}{ for period $(\mathrm{mm})$} & 975 & 1246 & 142 & 307 & 218 & 369 \\
\hline
\end{tabular}
Values are given as percentages of normal (1941-70); the stations are located by number in Fig. 1 . 
The Diamond Hinman radiosonde, used at all the six stations, is subject to failure beyond a temperature/ humidity threshold, indicated by the "motorboating" effect (Hutchings, 1961). The true mixing ratio is unknown in such situations, although it must lie between zero and the mixing ratio calculated using the cutout threshold temperature and humidity (Tomlinson, 1975). "Exclusive" values given in this paper refer to motorboating situations in which the mixing ratio was set to zero. "Inclusive" values are those where the mixing ratio has been calculated using the threshold values.

The main errors in computed values of water vapor parameters arise from instrumentation faults, such as the lag in humidity elements of the radiosondes and inadequate wind resolution. There are also the inevitable interpolation errors arising from the fact that water contents are measured at preselectetd points. These problems have been discussed by Hutchings (1957), Starr et al. (1969) and Peixoto (1973).

The "wet" and "dry" periods chosen for analysis were the wettest and driest year, summer and winter, that occurred within the 1960-73 period at the New Zealand radiosonde stations, as supported by "maps of rainfall departure from normal" and "summary of weather" contained in "Meteorological Observations" published by the New Zealand Meteorological Service. The chosen periods were also wetter and drier than normal (1941-1970 mean rainfall) as determined by calculating averages for the periods concerned using the same 20 stations as Tomlinson (1980) in his New Zealand series (Table 2).

The 20-station mean has secular variations closely similar to that of the spatial average incorporating all New Zealand stations (Tomlinson 1976, Salinger 1979), consistent with the wide dispersion of the 20 stations on both sides of the main mountain ranges (Fig. 1). Tomlinson (1976) notes that annual rainfall totals at each of 340 stations throughout New Zealand are correlated to one of these 20 stations with a correlation coefficient that is no worse than 0.70 . As a result, the average of the 20 stations can be used to represent "New Zealand rainfall" for each period. Some of the deviations from normal shown in Table 2 are small for New Zealand rainfall thus defined, because the data are averaged over space throughout the whole country.

\section{a. Dry year (1973)}

This year, rainfall in New Zealand was $84 \%$ of normal, or about two standard deviations below the long-term mean. All stations were drier than usual, except for Napier (station No. 8, Fig. 1) where rainfall was close to normal. The central part of the country was driest, with Kaikoura (No. 16) having only $58 \%$ of normal rainfall, or almost two and half standard deviations below the mean.

\section{b. Wet year (1968)}

Rainfalls were not excessively high, but 1968 rainfall was one standard deviation above the long-term mean. Over New Zealand rainfall was $107 \%$ of normal. Auckland (No. 2) and Dunedin (No. 19) both had $130 \%$ of normal rainfall (more than 1.5 standard deviations above the mean), but six stations in the central area of the North Island were drier than usual.

\section{c. Dry summer (1972-73)}

The summer was dry over the whole country, with New Zealand rainfall being $54 \%$ of normal. At Blenheim (No. 13), rainfall was only $12 \%$ of normal, and it was also very dry at Auckland (No. 2), Masterton (No. 10) and Nelson (No. 12).

\section{d. Wet summer (1965-66)}

New Zealand rainfall was $116 \%$ of normal. In the north, rainfall was more than $150 \%$ of normal, and Blenheim (No. 13) and Hokitika (No. 14) also received greater than $125 \%$. However, six stations were drier than usual, notably Christchurch (No. 17) and Kaikoura (No. 16).

\section{e. Dry winter (1969)}

Record low rainfalls occurred north and south of Christchurch, with Blenheim (No. 19) having $19 \%$ of normal. It was drier than normal at all stations, except at New Plymouth (No. 4) in the west of the North Island. Overall, New Zealand rainfall was $67 \%$ of normal.

\section{f. Wet winter (1968)}

Compared with long-term values, this was not an excessively wet year, but it did experience $114 \%$ of normal rainfall. The inland station of Alexandra (No. 18) had $182 \%$ of normal rainfall, and it exceeded $130 \%$ at Gisborne (No. 6), Napier (No. 8), and Kaikoura (No. 16). Five stations, mainly in the middle North Island, were drier than normal.

\section{Mean water vapor transfer over the Southwest Pacific \\ a. Zonal transfer}

Patterns of mean water vapor transfer over the Southwest Pacific for the period 1960-73 generally reflect the region's major wind systems. Fig. 2, obtained by drawing isolines of mean $Q \lambda_{L}$, shows that zonal transfers over the midlatitudes are predominantly westerly in direction. The zonal transfers over the subtropics, on the other hand, are characterized by low-level easterly transfer, and by a weak but extensive high-level westerly flow. The subtropical transfer patterns closely resemble the configuration of the east-west Walker Circulation as described by 


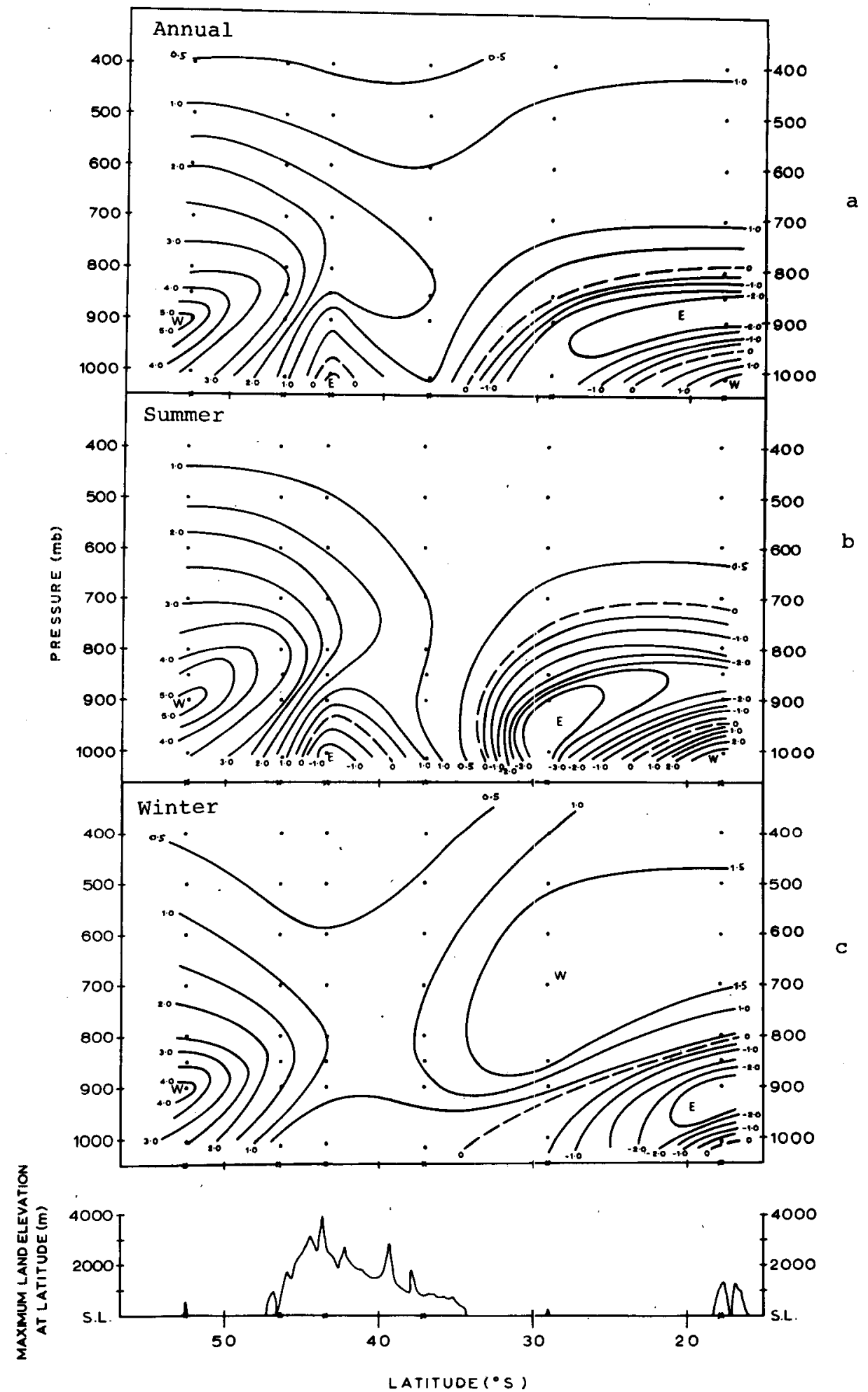

FIG. 2. Mean zonal transport of water vapor across $175^{\circ} \mathrm{E}$ from 1960 to 1973 : (a) annual, (b) summer and (c) winter. Units are $10^{-1} \mathrm{~kg} \mathrm{~m}^{-1} \mathrm{mb}^{-1} \mathrm{~s}^{-1}$. 

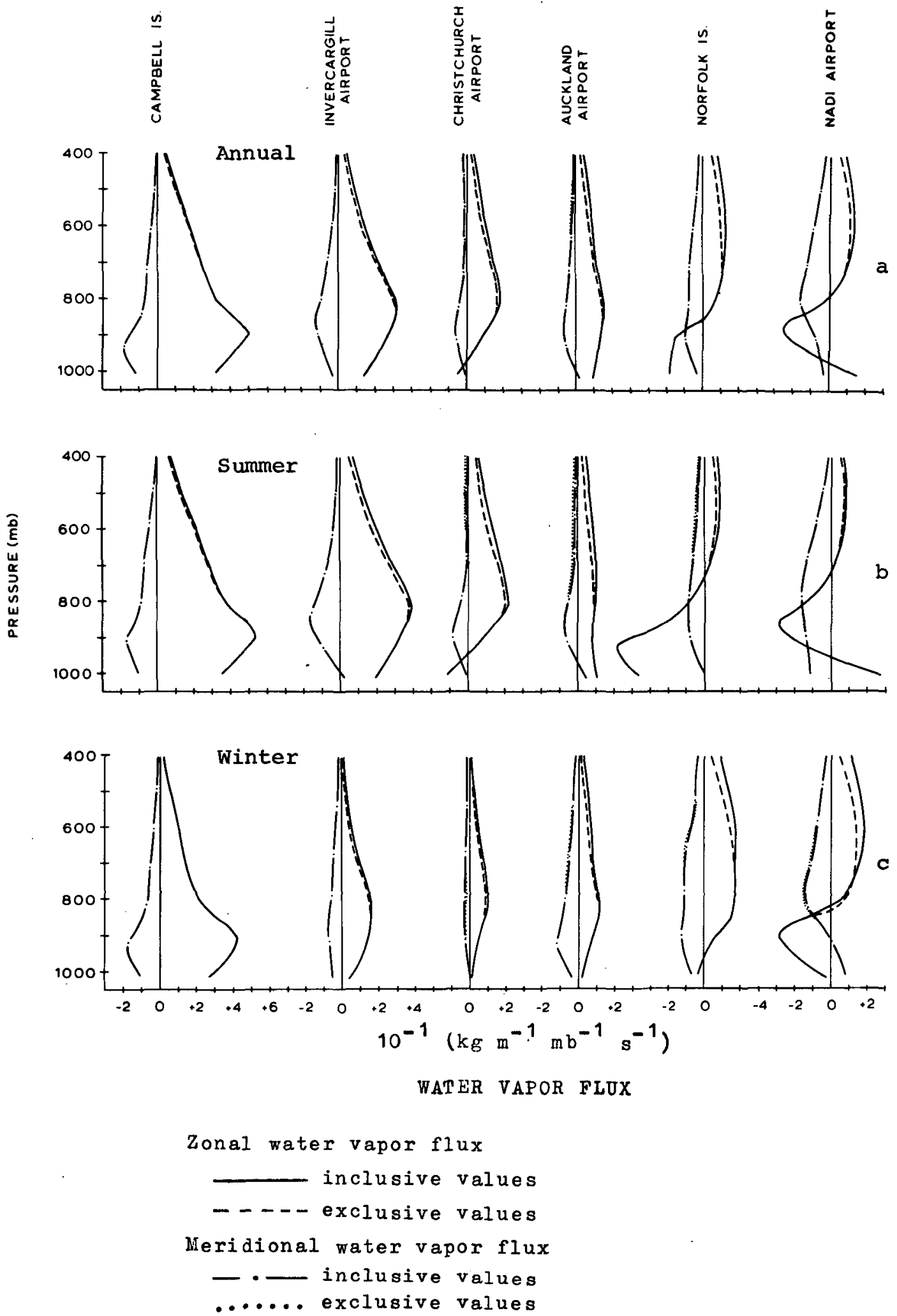

FIG. 3. Vertical distribution of mean zonal and meridional water vapor transfer at the six stations from 1960-1973: (a) annual, (b) summer and (c) winter. A negative value for zonal or meridional component in this and subsequent figures indicates that it is from the east or north, respectively. Units are $10^{-1} \mathrm{~kg} \mathrm{~m}^{-1} \mathrm{mb}^{-1} \mathrm{~s}^{-1}$. 


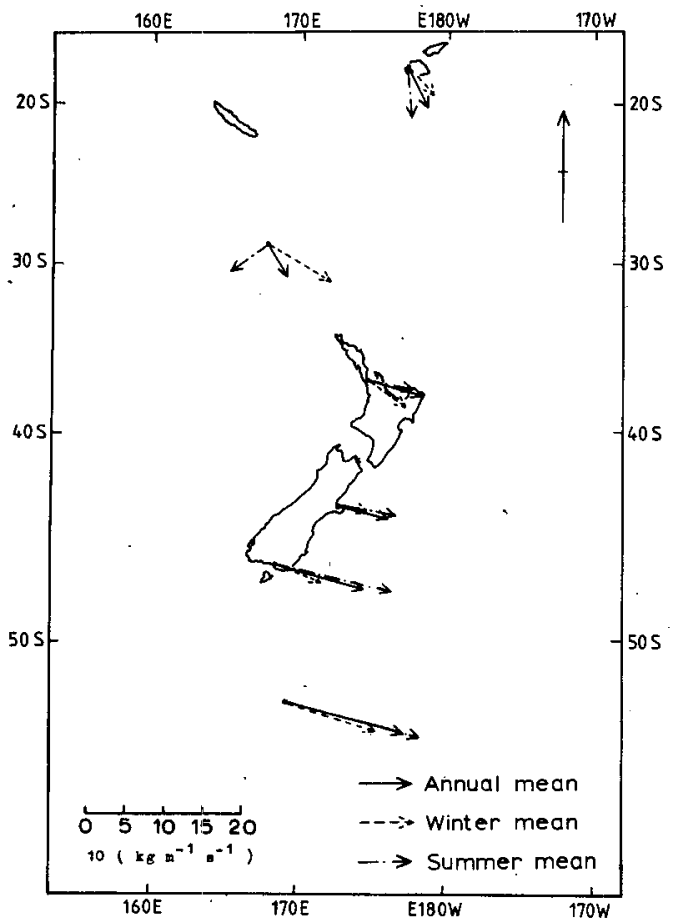

FiG. 4. Annual and seasonal means of vertically integrated vector transport of water vapor from 1960 to 1973 . Units are $10 \mathrm{~kg} \mathrm{~m}^{-1}$ $s^{-1}$.

Bjerknes (1969). When a station is sheltered by mountain ranges from moist prevailing winds, the patterns of the low-level transfer are modified, as at Nadi and Christchurch.
The zonal vapor transfers vary markedly with the seasons. In the winter months (June, July and August), the westerly component of the transfer plays a more dominant role than the easterly component. By contrast, during the summer months (December, January and February), the easterly component of the flow enlarges at the expense of the westerly component. Mean annual zonal transfer is determined by the summer pattern, except that the center of the subtropical easterly component is situated about $10^{\circ}$ farther north, and is weaker.

\section{b. Meridional transfer}

The contribution of the meridional transfer (values of $Q \phi_{L}$ ) to the total water vapor transfer of the Southwest Pacific is smaller than that of the zonal transfer (Fig. 3). At all latitudes, the meridional transfer is predominantly northerly in component and gerierally more developed in summer.

\section{c. Vector transfer of water vapor}

Analysis of vertically integrated vector transfer shows that the flux $\mathbf{Q}$ over the midlatitude region is mainly from the west (Fig. 4), with little variation in direction from season to season at Campbell Island, Invercargill and Christchurch. At these stations, the standard deviation of the direction of annual transport is less than $7^{\circ}$, compared with $16^{\circ}$ at Auckland, $33^{\circ}$ at Norfolk Island, and $18^{\circ}$ at Nadi. Thus over the subtropics, seasonal variations of direction are more marked. In summer, the mean vector flux is predom-

TABLE 3. Vertically integrated precipitable water $\left(10 \mathrm{~kg} \mathrm{~m}^{-2}\right)$ for wet and dry periods compared with average conditions for $1960-73$. I = inclusive value, $E=$ exclusive value.

\begin{tabular}{|c|c|c|c|c|c|c|c|c|c|}
\hline \multirow[b]{2}{*}{ Station } & \multicolumn{3}{|c|}{ Year } & \multicolumn{3}{|c|}{ Summer } & \multicolumn{3}{|c|}{ Winter } \\
\hline & Wet & Dry & $\begin{array}{l}\text { Average } \\
1960-73\end{array}$ & Wet & Dry & $\begin{array}{l}\text { Average } \\
1960-73\end{array}$ & Wet & Dry & $\begin{array}{l}\text { Average } \\
1960-73\end{array}$ \\
\hline \multicolumn{10}{|l|}{ Nadi } \\
\hline I & 4.01 & 4.00 & 4.08 & 4.37 & 4.68 & 4.64 & 3.60 & 3.58 & 3.50 \\
\hline $\mathbf{E}$ & 3.84 & 3.81 & 3.93 & 4.27 & 4.53 & 4.54 & 3.39 & 3.38 & 3.28 \\
\hline \multicolumn{10}{|c|}{ Norfolk Island } \\
\hline I & 2.45 & 2.61 & 2.55 & 3.32 & 3.06 & 3.01 & 1.84 & 1.96 & 2.07 \\
\hline $\mathbf{E}$ & 2.37 & 2.54 & 2.48 & 3.24 & 2.98 & 2.92 & 1.79 & 1.87 & 2.01 \\
\hline \multicolumn{10}{|l|}{ Auckland } \\
\hline I & 1.98 & 2.05 & 2.00 & 2.93 & 2.25 & 2.38 & 1.61 & 1.53 & 1.55 \\
\hline $\mathrm{E}$ & 1.84 & 1.89 & 1.85 & 2.76 & 2.06 & 2.19 & 1.46 & 1.40 & 1.41 \\
\hline \multicolumn{10}{|l|}{ Christchurch } \\
\hline I & 1.57 & 1.58 & 1.59 & 2.12 & 1.93 & 1.99 & 1.17 & 1.03 & 1.18 \\
\hline $\mathbf{E}$ & 1.47 & 1.46 & 1.49 & 2.02 & 1.81 & 1.87 & 1.06 & 0.91 & 1.06 \\
\hline \multicolumn{10}{|l|}{ Invercargill } \\
\hline I & 1.60 & 1.53 & 1.57 & 1.91 & 1.82 & 1.88 & $1.16^{\prime}$ & 1.18 & 1.19 \\
\hline $\mathbf{E}$ & 1.53 & 1.44 & 1.49 & 1.81 & 1.75 & 1.79 & 1.09 & 1.09 & 1.10 \\
\hline \multicolumn{10}{|c|}{ Campbell Island } \\
\hline I & 1.33 & 1.29 & 1.33 & 1.42 & 1.35 & 1.51 & 1.16 & 1.11 & 1.16 \\
\hline $\mathbf{E}$ & 1.33 & 1.29 & 1.32 & 1.42 & 1.35 & 1.50 & 1.16 & 1.11 & 1.16 \\
\hline
\end{tabular}


inantly from the north or northeast, while in winter, a northwest flow prevails. Significant changes in the flow patterns occur between latitudes $30^{\circ} \mathrm{S}$ and $37^{\circ} \mathrm{S}$, as the trade winds give way to the westerlies. This has also been noted by Reid (1982) in his analysis of surface wind frequencies along a similar transect. He

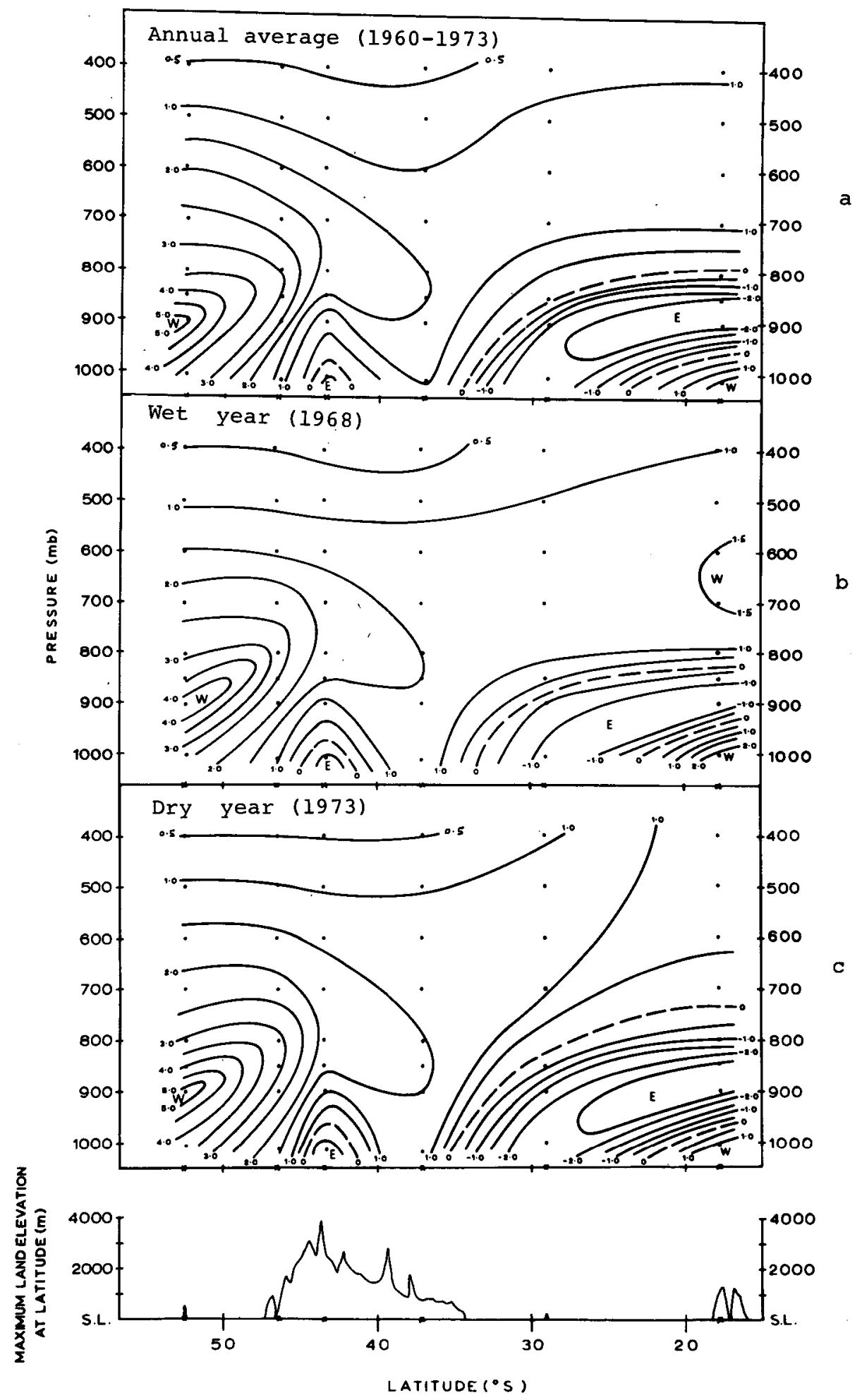

FIG. 5. Mean zonal transport of water vapor across $175^{\circ} \mathrm{E}$ for: (a) annual average (1960-1973), (b) wet year (1968) and (c) dry year (1973). Units are $10^{-1} \mathrm{~kg} \mathrm{~m}^{-1} \mathrm{mb}^{-1} \mathrm{~s}^{-1}$. 


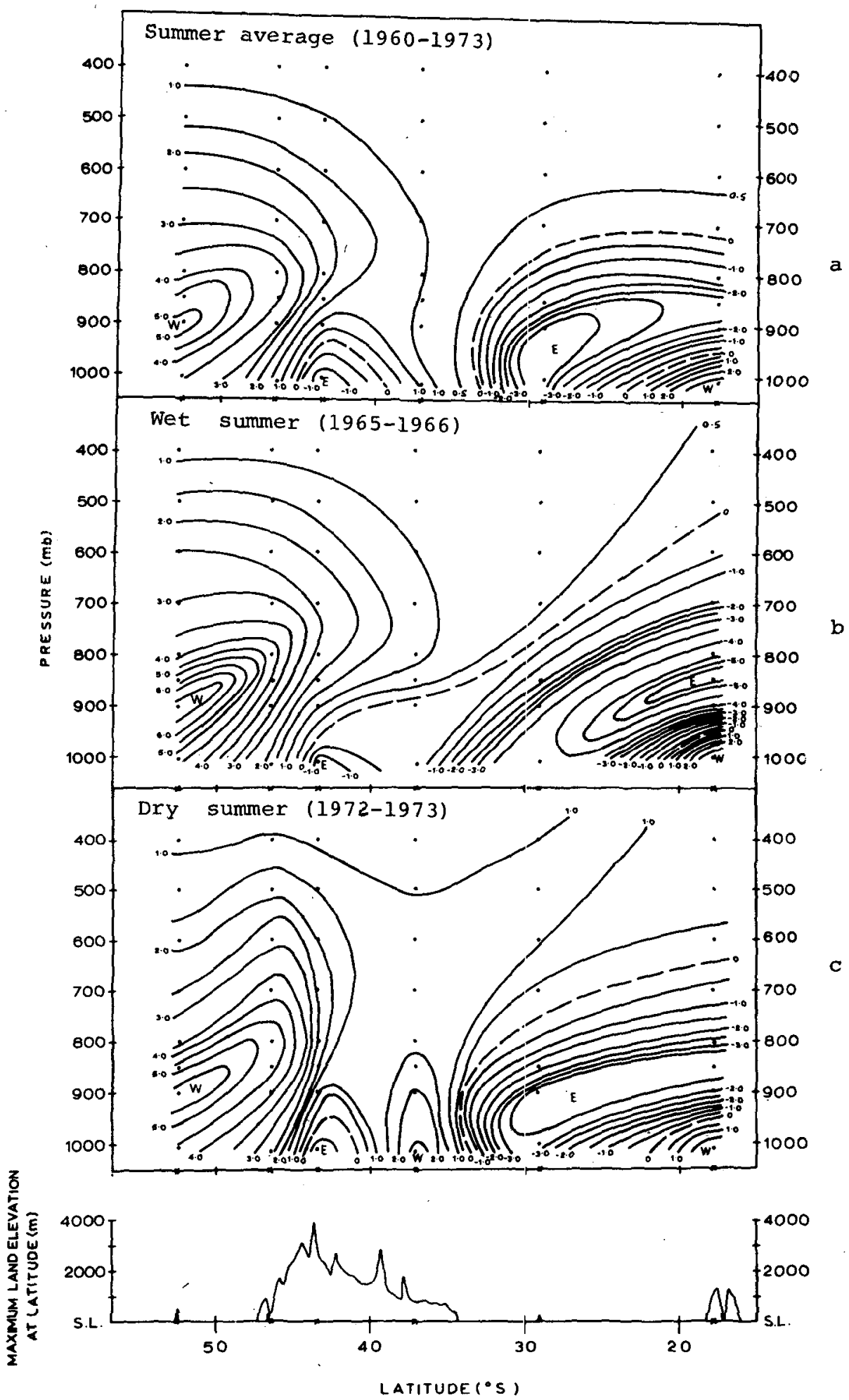

FiG. 6. Mean zonal transport of water vapor across $175^{\circ} \mathrm{E}$ for: (a) summer average (1960-73), (b) wet summer (1965-66) and (c) dry summer (1972-73). Junits are $10^{-1} \mathrm{~kg} \mathrm{~m}^{-1} \mathrm{mb}^{-1} \mathrm{~s}^{-1}$. 


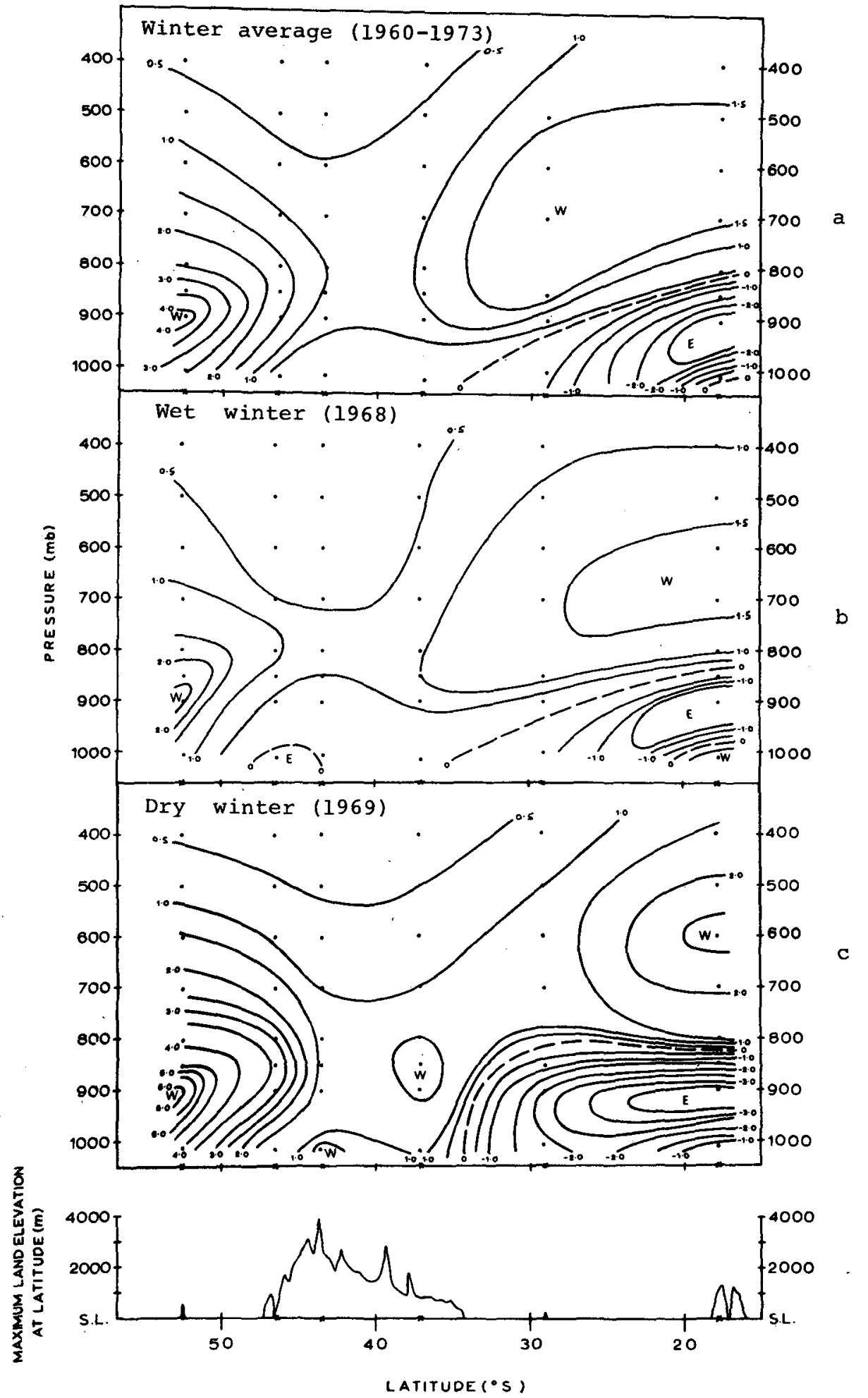

FIG. 7. Mean zonal transport of water vapor across $175^{\circ} \mathrm{E}$ for: (a) winter average (1960-73), (b) wet winter (1968), and (c) dry winter (1969). Units are $10^{-1} \mathrm{~kg} \mathrm{~m}^{-1} \mathrm{mb}^{-1} \mathrm{~s}^{-1}$. 

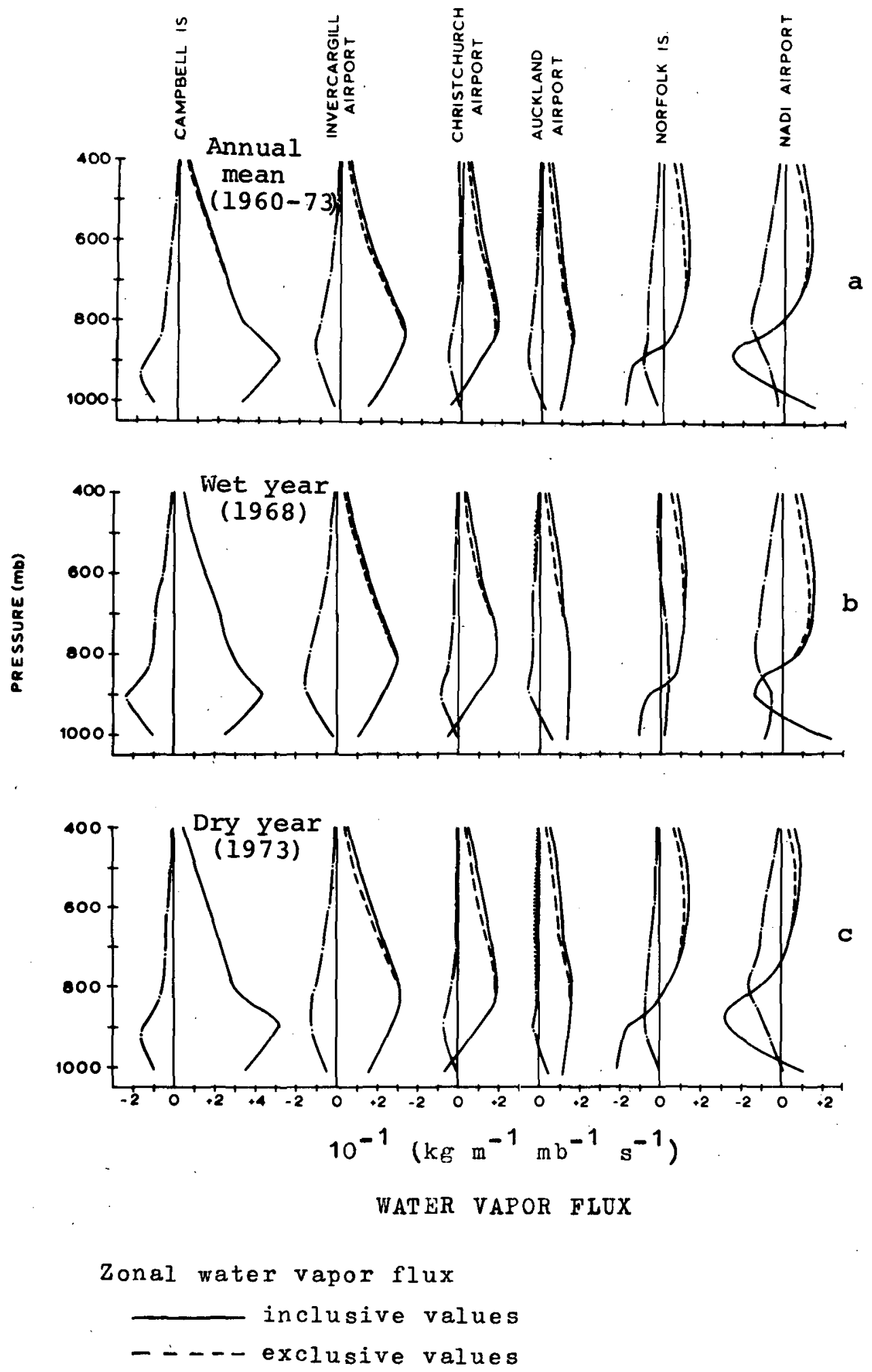

Meridional water vapor flux

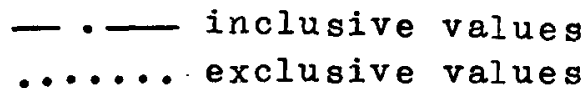

FIG. 8. Vertical distribution of mean zonal and meridional water vapor transfer at the six stations for: (a) annual average (1960-73), (b) wet year (1968) and (c) dry year (1973). Units are $10^{-1} \mathrm{~kg} \mathrm{~m}^{-1} \mathrm{mb}^{-1}$ $\mathbf{s}^{-1}$. 
found the broad scale change from tropical easterlies to midlatitudes occurred near the latitude of Auckland.

The magnitude of the mean water vapor vector transfer $\mathbf{Q}$ along the transect varies both with latitude and season (Fig. 4). The transfers at the latitudes of Campbell Island and Invercargill are considerably
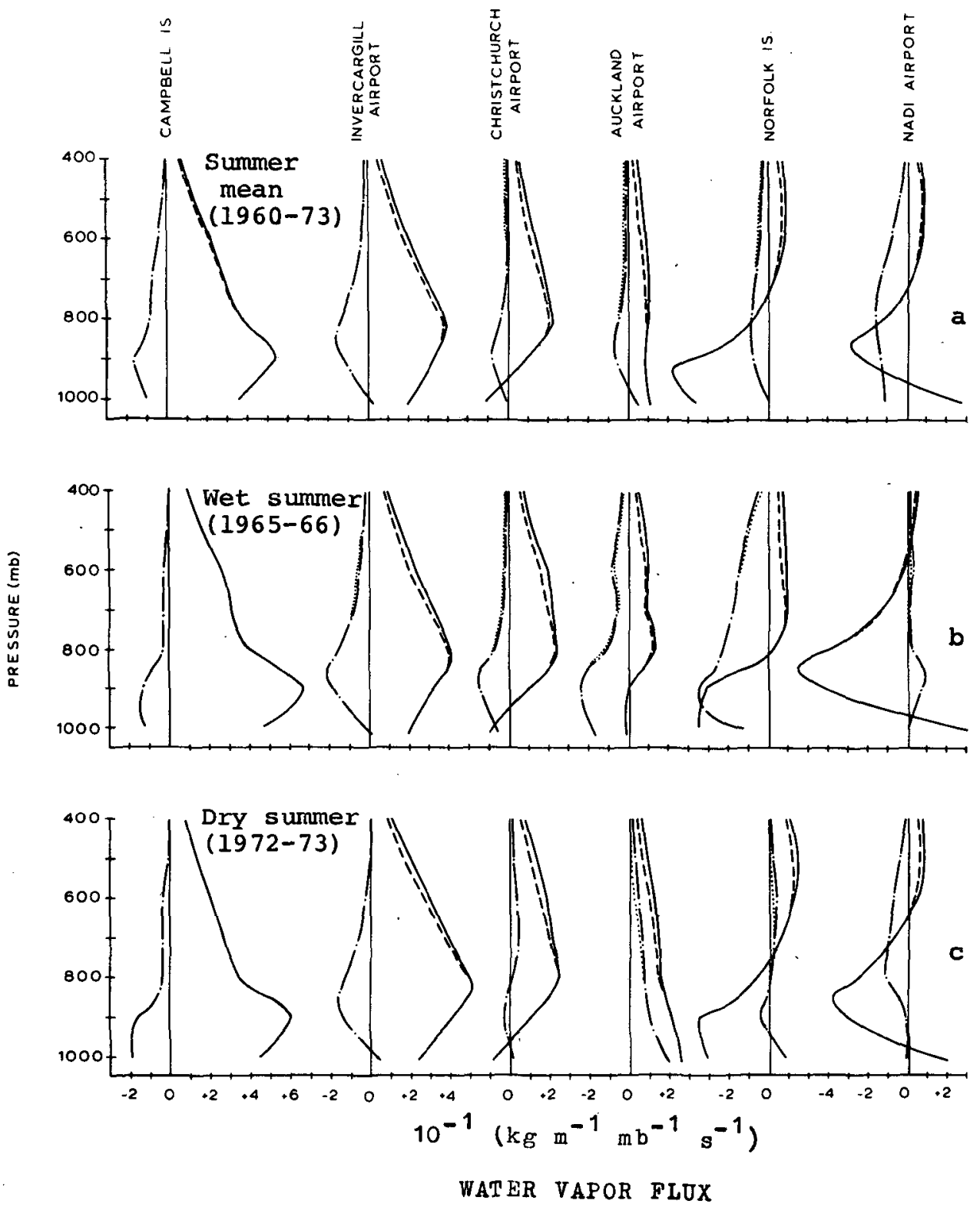

Zonal water vapor flux

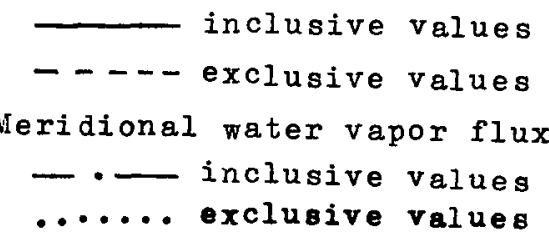

FIG. 9. Vertical distribution of mean zonal and meridional water vapor transfer at the six stations for: (a) summer average (1960-73), (b) wet summer (1965-66) and (c) dry summer (1972-73). Units are $10^{-1}$ $\mathrm{kg} \mathrm{m} \mathrm{mb}^{-1} \mathrm{~s}^{-1}$. 

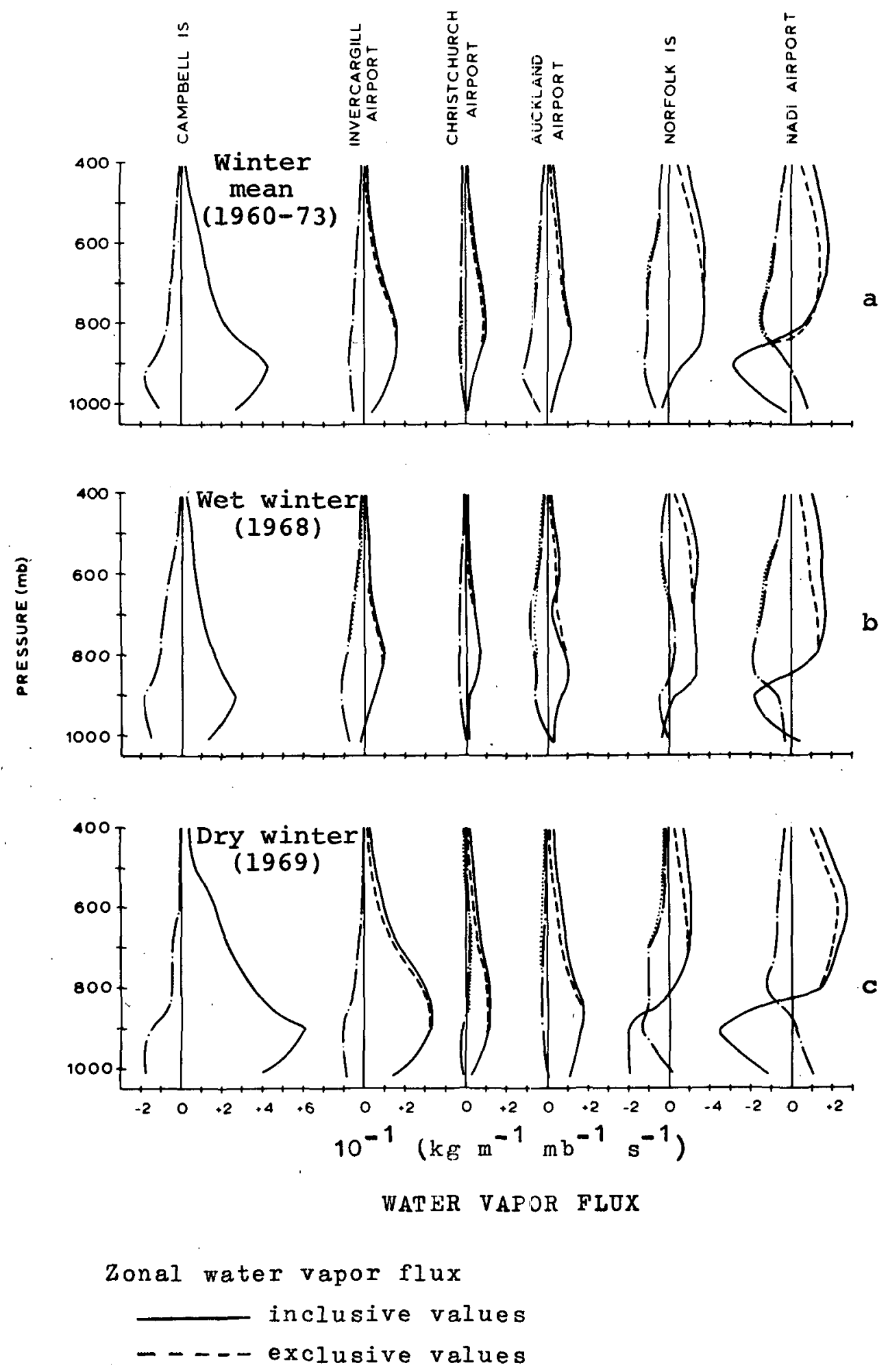

Meridional water vapor flux

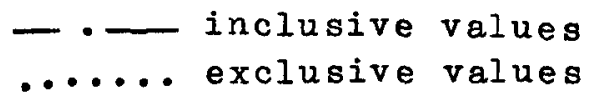

FIG. 10. Vertical distribution of mean zonal and meridional water vapor transfer at the six stations for: (a) winter average (1960-73), (b) wet winter (1968) and (c) dry winter (1969). Units are $10^{-1} \mathrm{~kg} \mathrm{~m}^{-1} \mathrm{mb}^{-1} \mathrm{~s}^{-1}$. 
larger than those at more northerly latitudes, consistent with the overall increase of wind speed with latitude. The standard deviation of the magnitude of the annual transport ranges from $14 \%$ of the mean for $1960-73$ at these two southern stations, to as large as $31 \%$ at Norfolk Island.

Except at Norfolk Island, the water vapor flux is greater in summer than in winter, the most notable seasonal differences being at Invercargill, where the summer flux is $128 \%$ of the mean and the winter flux just $51 \%$ of the mean. Such seasonal changes reflect some combination of changes in both wind speed and humidity, the latter being seen in the seasonal variation of precipitable water (Table 3 ). Precipitable water is larger in summer than in winter, varying from $10 \%$ about the average for the year at Campbell Island up to $25 \%$ at Christchurch. The majority of the summer increase in vapor flux and about half the winter decrease can be explained by changes in moisture at Campbell Island, Invercargill, Christchurch and Nadi. At Norfolk Island and Auckland seasonal wind speed variations are more important in controlling the magnitude of the flux. The three southern stations of the transect have higher average $900-400 \mathrm{mb}$ wind speed and precipitable water in summer than in winter. On the other hand, the three northern stations have a winter maximum of wind speed, and a summer maximum of precipitable water, so the relationship between vapor flux and these parameters changes with latitude.

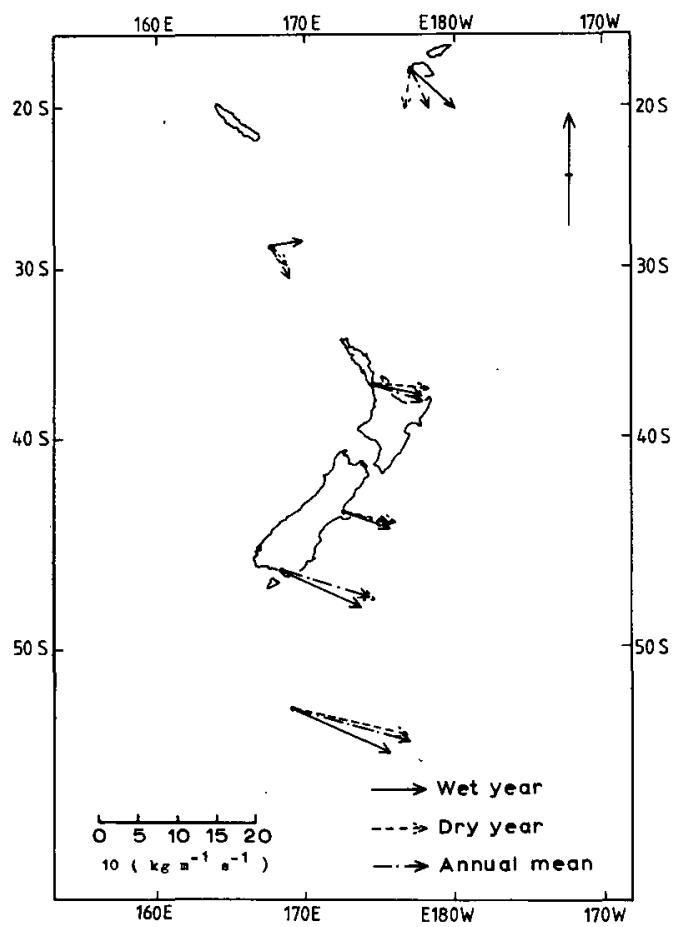

FIG. 11. Mean vertically integrated vector transport of water vapor: annual average (1960-73); wet year (1968) and dry year (1973). Units are $10 \mathrm{~kg} \mathrm{~m}^{-1} \mathrm{~s}^{-1}$.

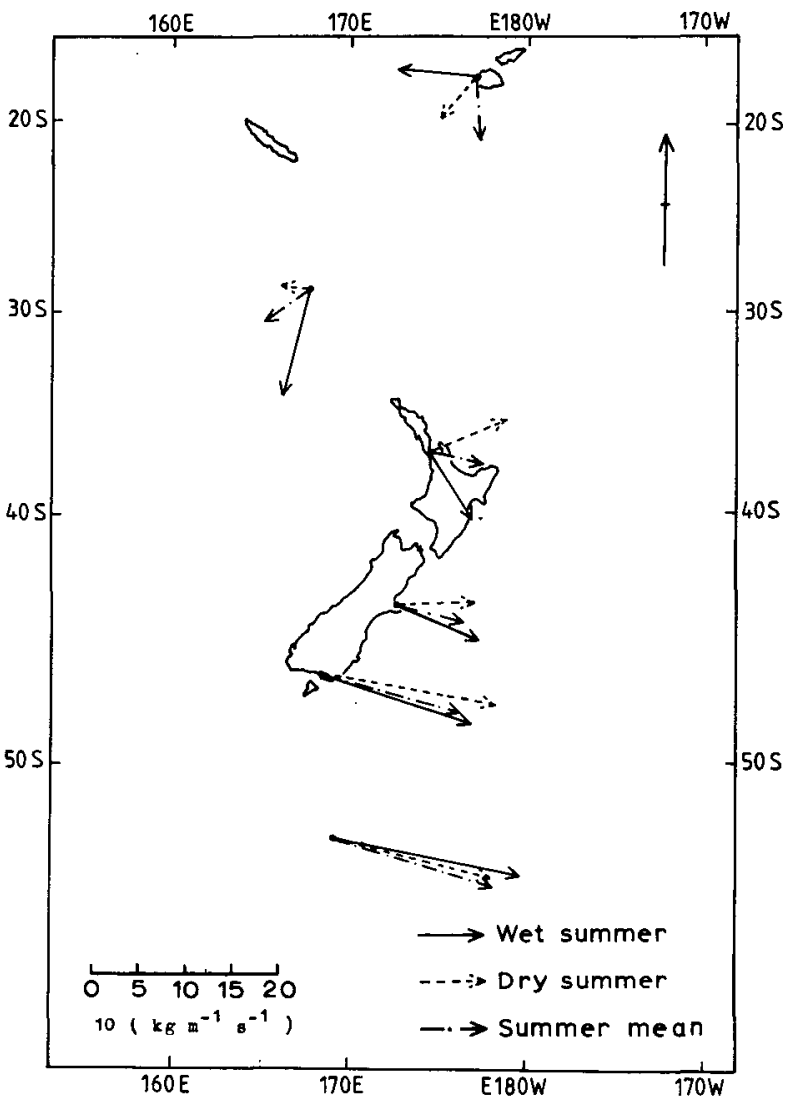

FIG. 12. Mean vertically integrated vector transport of water vapor for: summer average (1960-73); wet summer (1965-66), and dry summer (1972-73). Units are $10 \mathrm{~kg} \mathrm{~m}^{-1} \mathrm{~s}^{-1}$.

\section{Water vapor transfer characteristics during wet and dry rainfall periods over New Zealand}

The low-level easterly component of zonal water vapor transfer extends farther south during wet periods than it does during dry periods, or during the mean period 1960-73. This phenomenon is particularly marked in summer (Figs. 5-7). Conversely, during dry periods, the westerly transfer is more dominant.

During wet periods of $1960-73$, the meridional water vapor transfer tends to have a stronger northerly component than is the case for dry periods. This phenomenon is most pronounced over the New Zealand region (Figs. 8-10), which appears to be especially sensitive to the effects of shifts in the influence of the westerlies and trade winds.

The differing magnitudes of the northerly and westerly components are also evident in the directions of mean vertically integrated vector vapor transfers (Figs. 11-13). However, no consistent pattern of variation is apparent in their magnitude, or in precipitable water for wet and dry periods (Table 3). On the basis of those observations, both droughts and wetter periods in New Zealand tend to be related more to the direction of water vapor transfer, and 


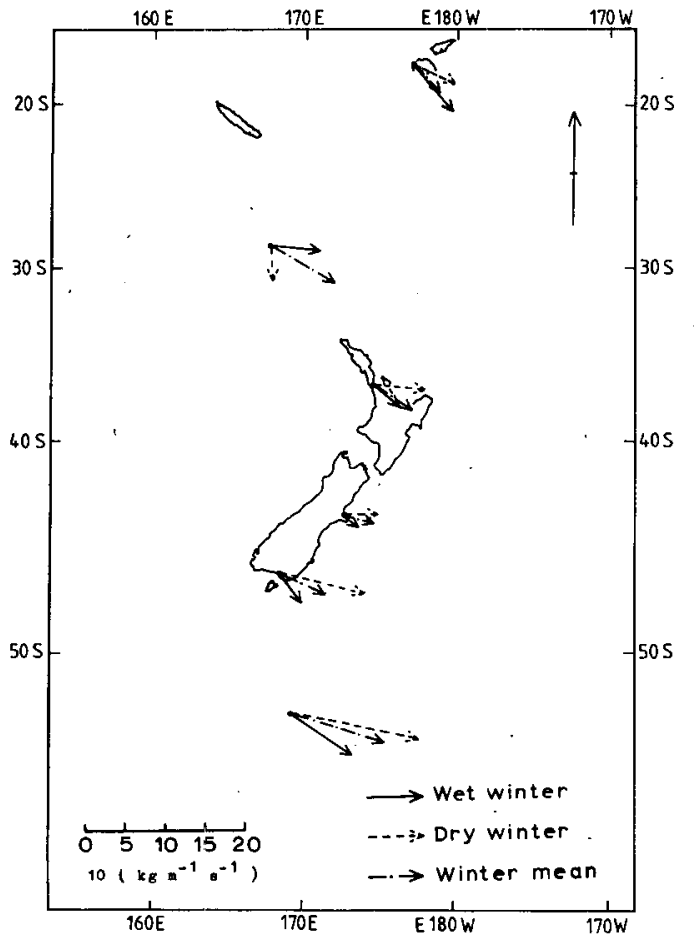

FIG. 13. Mean vertically integrated vector transport of water vapor for: winter average (1960-73); wet winter (1968) and dry winter (1969). Units are $10 \mathrm{~kg} \mathrm{~m}^{-1} \mathrm{~s}^{-1}$.

hence wind field changes, especially in summer, rather than to the magnitude of these transfers.

These points are illustrated further in Fig. 14, where the low level water vapor transfer vectors are plotted for individual summers at Auckland. Auckland data was chosen because the area is little influenced by orography and it is located in the latitude band especially sensitive to shifts in the large scale circulation patterns. The wet summer (1965-66) and dry summer (1972-73) plot in contrasting sectors of the diagram, and the data points are the farthest apart. The flux vectors of the wettest and driest summers differ from the less extreme ones in a consistent and clearly identifiable way.

\section{Discussion and conclusions}

The overall patterns of water vapor transfer established by the present analysis verify those established earlier by Starr et al. (1969), Peixoto (1972) and Peixoto et al. (1976). However, the magnitude and location of the various transfer centers, here defined by more observations and over a longer period, differ considerably. Daily wind and humidity data used in earlier studies were restricted to four or five pressure levels $(1000,850,700,500$, and in some cases 300 $\mathrm{mb}$ ) rather than the eight or more considered here.

In particular, the patterns of zonal transfer differ markedly from those of zonally averaged transfer during the IGY as obtained by Peixoto et al. (1976) for a meridional cross section of the Southern and Northern Hemispheres. They indicated that the zonally averaged subtropical easterly transfer was more developed in winter than in summer. This is also suggested for the New Zealand longitudes in their Figs. 1 and 2, a fact not confirmed by the present analysis, which demonstrates that over 1960-73 the subtropical easterly transfer is strongest in summer. In addition, the center of the midlatitude westerly transfer is $10^{\circ}$ farther poleward than that indicated by Peixoto et al. Consequently the line of zero zonal flux, which separates the subtropical easterly transfer from the midlatitude westerly transfer, is also located at higher latitude than that given by Peixoto et al. These results therefore support Taljaard (1972) and Trenberth (1981) who note that there are anomalies in the circulation of the Australian-Western Pacific region.

Rosen et al. (1979) discovered a wide range of interannual variability in atmospheric water vapor transport in the Northern Hemisphere, which is here shown to extend southward into the west Pacific. Over New Zealand, wet periods are produced by a wider latitudinal distribution of low-level easterly wind regimes and vapor transfer, or expansion of the Hadley cell. Dry conditions are accompanied by a weakening of the Hadley cell and strengthening of the Ferrel cell as represented by the westerly wind regime and vapor transfer.

The wet and dry periods during 1960-73, were accompanied by only small changes in the magnitude of the water vapor flux and humidity, but by large

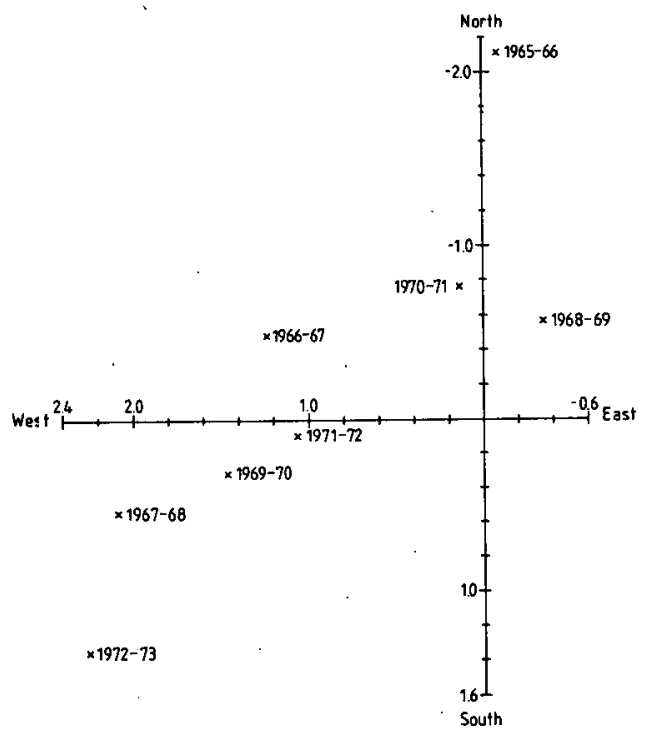

FiG. 14. Vector diagram of the mean of the surface and $900 \mathrm{mb}$ zonal and meridional water vapor transfer over Auckland for each summer from 1965 to 1973 . Vector is obtained by drawing the line from the cross to the origin. Units are $10^{-1} \mathrm{~kg} \mathrm{~m}^{-1} \mathrm{mb}^{-1} \mathrm{~s}^{-1}$. 
changes in the flux direction, especially in summer. These changes are produced mainly by changes in the large scale wind regime, with wetter summers associated with enhanced lower tropospheric northeast flow. These findings are consistent with current notions of the circulation changes that accompany wet and dry periods over New Zealand. Steiner (1968) and Salinger (1980) note that widespread, unsettled weather over much of north and east New Zealand is associated with easterly regimes. In contrast, dry conditions over eastern districts are often associated with the predominance of westerly regimes, with frontal disturbances separating migratory anticyclone cells (Hill, 1971; Salinger, 1980).

Acknowledgments. The authors thank the New Zealand Meteorological Service and Australian Bureau of Meteorology for providing the necessary data used in this study.

\section{REFERENCES}

Bjerknes, J., 1969: Atmospheric teleconnections from the equatorial Pacific. Mon. Wea. Rev., 97, 163-172.

Hastenrath, S., and L. Heller, 1977: Dynamics of climatic hazards in northeast Brazil. Quart. J. Roy. Meteor. Soc., 103, 77-92.

Hill, H. W., 1971: Some synoptic aspects of drought in New Zealand in the summer 1969-70. N.Z. Meteor. Service Tech. Note, No. 194. [Available from New Zealand Meteorological Service, P.O. Box 722, Wellington, New Zealand.]

Hutchings, J. W., 1957: Water-vapour flux and flux-divergence over southern England: Summer 1954. Quart. J. Roy. Meteor. Soc., 83, 30-48.

- 1961: Water-vapor transfer over the Australian continent. $J$. Meteor., 18, 615-634.

Kanamitsu, M., and T. N. Krishnamurti, 1978: Northern summer tropical circulations during drought and normal rainfall months. Mon. Wea. Rev., 106, 331-347.

Kidson, J. W., 1977: African rainfall and its relation to the upper air circulation. Quart. J. Roy. Meteor. Soc., 103, 441-456.

Nicholson, S. E., 1981: Rainfall and atmospheric circulation during drought periods and wetter years in West Africa. Mon. Wea. Rev., 109, 2191-2208.
Peixoto, J. P., 1972: Pole-to-pole water balance for the IGY from aerological data. Nordic Hydrol., 3, 22-43.

, 1973: Atmospheric vapour flux computations for hydrological purposes. WMO/IHD Projects Rep. No. 20, WMO, Geneva, 83 pp.

- R. D. Rosen and M. F. Wu, 1976: Seasonal variability in the pole-to-pole water vapor balance during the IGY. Nordic Hydrol., 7, 95-114.

,-- and D. A. Salstein, 1978: Seasonal variability in the pole-to-pole modes of water vapor transport during the IGY. Arch. Meteor. Geophys. Bioklim., A27, 233-255.

Reid, S. J., 1982: Surface wind frequencies in the southwest Pacific estimated from radar wind data. N.Z. J. Science, 25, 303-311.

Rosen, R. D., D. A. Salstein and J. P. Peixoto, 1979: Variability in the annual fields of large scale atmospheric water vapor transport. Mon. Wea. Rev., 107, 26-37.

Salinger, M. J., 1979: Climatic regions of New Zealand based on cluster techniques. N.Z. Statistician, 14, 26-34.

, 1980: New Zealand climate. Part I: Precipitation patterns. Mon. Wea. Rev., 108, 1892-1904.

Starr, V. P., and J. P. Peixoto, 1971: Pole-to-pole eddy transport of water vapor in the atmosphere during the IGY. Arch. Meteor. Geophys. Bioklim., A20, 85-114.

- - and R. G. McKean, 1969: Pole-to-pole moisture conditions for the IGY. Pure Appl. Geophys., 75, 300-331.

Steiner, J. T., 1968: The climatology of the New Zealand-South Pacific region. N.Z. Meteor. Service Tech. Information Circular, No. 124. [Available from New Zealand Meteorological Service, P.O. Box. 722, Wellington New Zealand.]

Taljaard, J. J., 1972: Synoptic meteorology of the Southern Hemisphere. Meteorology of the Southern Hemisphere, Meteor. Monogr., No. 35, Amer. Meteor. Soc., 139-211.

Tomlinson, A. I., 1975: Upper air statistics for New Zealand stations. N.Z. Meteor. Service Misc. Publ., No. 147. [Available from New Zealand Meteorological Service, P.O. Box. 722, Wellington, New Zealand.]

- 1976: Short period fluctuations of New Zealand rainfall. N.Z. J. Science, 19, 149-161.

, 1980: A non-random feature in New Zealand rainfall. N.Z. Geographer, 36, 68-72.

Trenberth, K. E., 1977: Relationships between inflow to Clutha Lakes, broad-scale atmospheric circulation parameters, and rainfall. N.Z. J. Science, 20, 63-71.

- 1981: Southern Hemisphere general circulation and its variability. Weather and Climate, 1, 21-26.

Vines, R. G., and A. I. Tomlinson, 1980: An analysis of New Zealand's rainfall. N.Z. J. Science, 23, 205-216. 